\title{
Genetic Differences in Drug Disposition
}

\author{
D. Gail May, MD
}

\begin{abstract}
Genetic polymorphisms of drug metabolizing enzymes are well recognized. This review presents molecular mechanisms, ontogeny and clinical implications of genetically determined intersubject variation in some of these enzymes. Included are the polymorphic enzymes N-acetyl transferase, cytochromes P4502D6 and 2C, which have been well described in humans. Information regarding other Phase I and Phase II polymorphic pathways, such as glutathione and methyl conjugation and alcohol and acetaldehyde oxidation continues to increase and are also discussed. Genetic factors effecting enzyme activity are frequently important determinants of the disposition of drugs and their efficacy and toxicity. In addition, associations between genetic differences in these enzymes and susceptibility to carcinogens and teratogens have been reported. Ultimately, the application of knowledge regarding these genetic factors of enzyme activity may guide medical therapy and minimize xenobiotic-induced disease.
\end{abstract}

$\mathbf{T}$ he recognition of the importance of intersubject variation in drug metabolism has increased markedly over the past 20 years. Intersubject variation may be genetically determined, environmentally induced, or more commonly, a combination of both. Pharmacogenetics is the study of the inherited traits that are responsible for unusual responses to drugs or xenobiotics. The inherited traits determining drug disposition may be either genetic polymorphisms, defined as Mendelian traits that exist in the population in at least two phenotypes neither of which is rare, or rare single gene defects. Genetically determined variation in drug disposition leads to responses that may be immediate, subacute, or delayed and may be either positive or adverse. The clinical consequences of genetic polymorphisms includes increased risk of adverse drug reactions, a lack of efficacy, or an association with disease states. The identification of patients with genetic predisposition using history, screening tests, and family studies may allow a priori dosage adjustment, alterations in time scheduling of therapeutic monitoring, or the use of drug alternatives. In this review, the Cytochrome $\mathrm{P} 450$ oxidative polymorphisms and $\mathrm{N}$-acetylation are detailed as the best studied examples of

From the Departments of Pediatrics and Pharmacology, Wayne State University, Children's Hospital of Michigan, Detroit, Michigan. Address for reprints: Gail May, MD, Departments of Pediatrics and PharmacolOgy. Wayne State University, Children's Hospital of Michigan, 3901 Beaubien, Room 3N47, Detroit, MI 48201. phase I and phase II genetic polymorphisms. Other genetically polymorphic pathways, including glutathione and methyl conjugation and alcohol and acetaldehyde oxidation, as well as the genetic polymorphism of aryl hydrocarbon hydroxylase induction, are also briefly described. Maturation of the polymorphic pathways is summarized, and examples of resulting kinetic, therapeutic, and toxic differences are presented. Data regarding potential differences in susceptibility to xenobiotic-induced diseases, including carcinogenesis and teratogenesis are outlined.

\section{THE EVOLUTION OF KNOWLEDGE}

Drug metabolism polymorphisms have been typically discovered after observations of marked intersubject differences in drug response during preclinical or clinical trials. Subsequently, definitive pharmacokinetic studies in which individuals were given an oral dose of probe drug and either plasma or urine collected were performed. For urinary sampling, the ratio of the total urinary yield of the parent drug over 8 hours to the total urinary yield of metabolite was calculated as the metabolic ratio. Next, the metabolic ratios of large populations were evaluated using either frequency histograms or normit plots. Bimodal distributions suggested two populations of phenotypes, termed extensive and poor metabolizers. Family studies confirmed the genetic nature of phenotypic bimodality. For some of the genetic polymorphisms, the responsible enzymes have been 
isolated, and the antibodies subsequently raised have permitted studies of substrate specificity.

Utilization of multiple molecular biology tools has clarified fine details of the structure of some of the involved genes and the definition of the mutations causing absent or defective proteins, allowing the development of simple tests to detect these mutations. An insertion, deletion, or rearrangement mutation in either the regulatory or structural sequence of the gene for a drug-metabolizing enzyme may decrease intracellular concentration or eliminate the enzyme protein or may structurally alter the enzyme with consequent changes in enzyme function. A defect in transcription, RNA processing or RNA stability may occur. At the protein level, either a decreased intracellular concentration or total absence of the protein may occur secondary to a diminished rate of synthesis or an accelerated degradation. Alternatively, there may be a normal intracellular concentration of a mutant enzyme protein. Finally, an enzyme may be structurally intact, but exhibit decreased affinity or maximal velocity for substrates or a change in stereoselectivity.

\section{N-ACETYLATION (N-ACETYLTRANSFERASE-2)}

The earliest described and most widely recognized genetic polymorphism of drug metabolism is that of $\mathrm{N}$-acetylation. This polymorphism affects the disposition of many diverse xenobiotics (Table I). Using one of several probe compounds, including isoniazid, sulfadimidine, procainamide, caffeine, dapsone, sulfamethazine or isoniazid, individuals may be separated into either fast or slow acetylator phenotypes. About half of Caucasian populations are slow acetylators. Compared with fast acetylators, slow acetylators achieve a higher parent drug blood concentration after the usual therapeutic dose of acetylated drugs and are more likely to develop unwanted effects. These toxic effects include sulfasalazine-induced hemolysis and hydrazine or arylamine-induced peripheral neuropathy and lupus erythematosus. $^{1-4}$ The relationship between acetylator phenotype and therapeutic response is less clear; however, on the basis of higher cure rates in slow acetylators, ${ }^{3}$ it has been advocated that rapid acetylators with pulmonary tuberculosis receive twice weekly isoniazid, while slow acetylators are treated once a week.

Two enzymes catalyzing $\mathrm{N}$-acetylation, $\mathrm{N}$-Acetyltransferase 1 and 2 (NAT1 and NAT2), are expressed in human liver, and both show selectivity for arylamine substrates. ${ }^{6}$ NAT1 has higher affinity and substrate turnover for monomorphic arylamines, such as p-aminosalicylic acid and p-aminobenzoic acid,

\section{TABLE I}

\begin{tabular}{c} 
Drugs and Other Environmental Chemicals Subject \\
to Polymorphic Acetylation in Humans \\
\hline Hydrazines \\
Isoniazid \\
Hydralazine \\
Phenelzine \\
Acetylhydrazine \\
Hydrazine \\
Arylamines \\
Procainamide \\
Dapsone \\
Sulfamethazine \\
Sulfapyridine \\
Aminoglutethimide \\
Carcinogenic arylamines \\
Benzidine \\
2-aminofluorene \\
$\beta$-naphthylamine \\
4-aminobiphenyl \\
Drugs metabolized to amine \\
Sulfasalazine \\
Nitrazepam \\
Clonazepam \\
Caffeine \\
Acebutolol
\end{tabular}

while NAT2 isoforms have higher affinity for the polymorphic arylamines substrates, such as sulfamethazine and procainamide. Thus, the NAT2 enzyme is responsible for the genetic polymorphism of $\mathrm{N}$-acetylation. The detailed human tissue distribution of NAT1 and NAT2 remains to be determined, but it seems likely from the rabbit model that NAT2 is present in liver and gut, while NAT1 is present more widely. ${ }^{7}$ From the arylamine substrate specificity of human peripheral blood cells, the acetylation enzyme present in blood is almost certainly NAT1 $1{ }^{8,9}$ The enzyme NAT2 exists as two isoforms, NAT2A and NAT2B. In genetically slow acetylators, the liver content of both NAT2A and NAT2B is markedly reduced. ${ }^{10}$

NAT1 and NAT2 are encoded at two genetic loci on chromosome 8. ${ }^{11} \mathrm{~A}$ lack of correlation of NAT1 and NAT2 enzyme activities in the human liver cytosol suggests that the two genes are independently regulated. ${ }^{6}$ Isolation of the DNA and corresponding cDNA for the polymorphic NAT2 locus has been well described. ${ }^{11-13}$ Using PCR and NAT2 specific oligonucleotide primers, at least 4 alleles, one fast (F1) and 3 slow (S1, S2, and S3) may be present at the polymorphic NAT2 locus. ${ }^{14,15}$ The fast allele in both heterozygotes and homozygotes produces the fast phenotype. In homozygotes, the three slow alleles are associated with slow acetylation in vivo without significant difference in the resulting acetylation ac- 
tivities among the three alleles. In either autopsied livers or in transfected cells, the mRNA levels determined by the three mutant alleles are not different from mRNA levels from the fast F1 allele, suggesting that the difference in NAT activity is mainly determined by the amount of enzyme protein. ${ }^{15}$ In Caucasians, the most common allele at the polymorphic NAT locus in Caucasians is the $S 1$ which has a frequency of $45 \% .{ }^{14}$ In the Japanese population, the absence of this allele in association with a $68 \%$ frequency of the F1 allele explains the markedly lower incidence of slow acetylation (6.6\%) in this population. ${ }^{14.16}$

\section{DEBRISOQUINE/SPARTEINE (CYTOCHROME P450 2D6)}

The genetic polymorphism associated with debrisoquine and sparteine metabolism is the first and most fully described genetic polymorphism of a Cytochrome P450 enzyme. The observation of unusual subject sensitivity to the hypotensive effects of debrisoquine led to this discovery. ${ }^{17}$ Contemporaneously, German investigators identified a polymorphism from observations of unusual neurologic side effects in some patients treated with the oxytocic agent sparteine. ${ }^{18}$ From cosegregation of poor metabolizers $^{19}$ and from competitive inhibition studies, ${ }^{20}$ these polymorphic responses were shown to reflect differences in the activity of the same Cytochrome P450 enzyme, currently labeled Cytochrome P450 2D6 (CYP2D6). Using the metabolic ratio of parent drug to its 4-hydroxymetabolite, investigators separated individuals into extensive and poor metabolizer phenotypes and found $7-10 \%$ of Caucasian populations deficient in the activity of this enzyme. ${ }^{21,22}$

Purification and characterization of the responsible enzyme led to studies that confirmed the cosegregation of debrisoquine and sparteine, bufuralol, encainide, and propranolol and allowed the development of specific polyclonal antibodies, which has allowed substrate specificity studies. ${ }^{23}$ The large number of drugs that are oxidized by CYP2D6 (Table II) and the 10-20 fold difference in disposition of some of these substrates account for the tremendous clinical interest in this polymorphism. Multiple drugs lack cosegregation with the debrisoquine polymorphism (Table III). Although criteria have not been formed to structurally assess whether a compound is metabolized by this enzyme a priori, all CYP2D6 metabolized substrates have a basic nitrogen and are oxidized at a site within $0.5-0.7 \mathrm{~nm}$ of this basic nitrogen. ${ }^{24}$ Not only does the polymor-

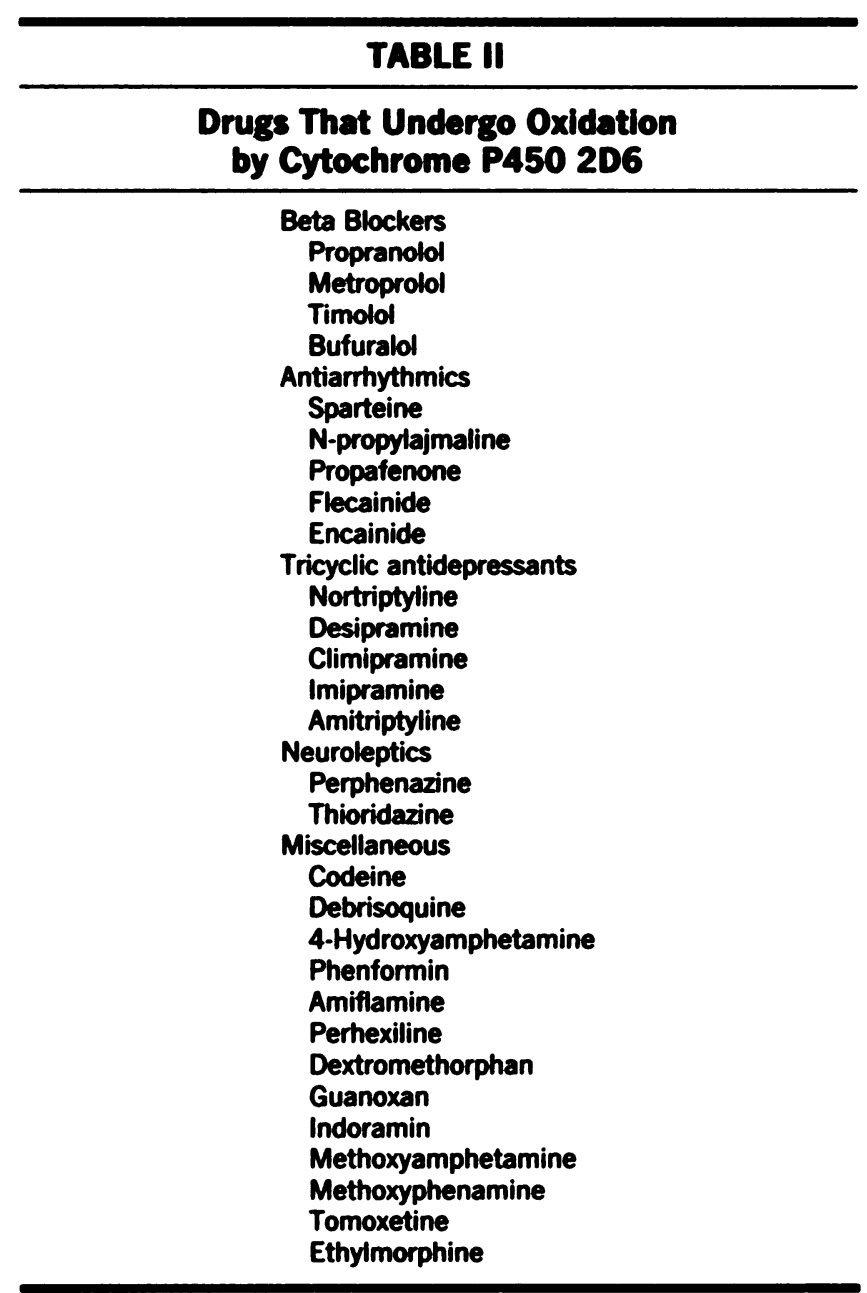

phism alter the rate of metabolism, the stereoselectivity of CYP2D6 may also be modified. In extensive metabolizers, inactive R-metoprolol is metabolized faster than the active S-enantiomer, whereas metabolism is not stereoselective in poor metabolizers. ${ }^{25}$ For some substrates, such as imipramine, the disposition of CYP2D6 substrates may exhibit nonlinear kinetics in extensive metabolizers but linear kinetics in poor metabolizers. ${ }^{26}$ Phenotypic differences may be reduced by functional impairment of the enzyme in extensive metabolizers. For example, quinidine is a competitive inhibitor that almost completely abolishes the in vivo metabolism of debrisoquine. ${ }^{27}$ Hence, a genetic extensive metabolizer taking quinidine would phenotypically appear to be a poor metabolizer. Other compounds that inhibit debrisquine metabolism in vivo include thioridazine, levomepromazine, and propafenone. ${ }^{28.29}$ Compounds that competitively inhibit enzyme activity in vitro which 


\begin{tabular}{cl}
\hline \multicolumn{1}{c}{ TABLE III } \\
\hline $\begin{array}{c}\text { Drugs That Are Not Eliminated } \\
\text { by Cytochrome P450 206 }\end{array}$ \\
\hline \\
\hline Alfentanil \\
Acetanilide \\
Amobarbital \\
Antipyrine \\
Carbamazepine \\
Carboxymethylcysteine \\
Cholesterol \\
Cyclosporine \\
Desmethyldiazepam \\
Diazepam \\
Ethinyloestradiol \\
Ethosuximide \\
Haloperidol \\
Maprotiline \\
Mephenytoin \\
Methaqualone \\
Midazolam \\
Nifedipine \\
Phenytoin \\
Pinacidil \\
Prazosin \\
Propranolol \\
Quinidine \\
Theophylline \\
Tolbutamide \\
\hline
\end{tabular}

may be in vivo inhibitors include important drugs such as haloperidol, fluphenazine and trifluperidol, metoclopramide, apomorphine, phenylcyclopropylamine, diphenhydramine and nicardipine and the estrogen norethindrone acetate. ${ }^{30}$ These compounds likely bind to CYP2D6 and might convert a genetically extensive metabolizer to a phenotypic poor metabolizer. Inducers of CYP2D6, such as antipyrine and rifampicin, will exaggerate the differences observed in metabolic ratios between extensive and poor metabolizers, but have minimal effect on drug elimination. ${ }^{31}$

The debrisoquine/sparteine polymorphism is caused by mutations of the CYP2D6 gene, which is part of a gene cluster on chromosome 22 that includes several related pseudogenes. ${ }^{32}$ Analysis of genotype may be performed using allele-specific probing of PCR amplified DNA. Restriction fragment length polymorphism (RFLP) analysis after digestion with the endonuclease $\mathrm{XbaI}$ usually results in fragments of 29,44 , and $11.5 \mathrm{~kb}$ length, ${ }^{33}$ or in a smaller number of individuals, $16+9 \mathrm{~kb}^{34}$ Unfortunately, RFLP analysis does not distinguish between extensive and poor metabolizers because a $44 \mathrm{~kb}$ and a 29 kb fragment may occur in both. A $29 \mathrm{~kb}$ fragment may represent either the wild type (normal) allele or may represent mutant alleles, called 2D6(A) and
2D6(B). The 2D6(A) mutant allele features a deletion in exon 5, while the 2D6(B) mutant allele contains multiple mutations leading to a splicing defect. ${ }^{35}$ Some individuals with the 2D6(B) mutation and splicing defect, have an additional gene in the cluster that renders a $44 \mathrm{~kb}$ fragment instead of a $29 \mathrm{~kb}$ fragment. ${ }^{36}$ In Chinese populations, a large segment of the population has a $44 \mathrm{~kb}$ fragment associated with the gene insertion, but without the splicing defect. ${ }^{37}$ These individuals are extensive metabolizers in contrast to Caucasians with a $\mathbf{4 4} \mathrm{kb}$ fragment who are poor metabolizers. The 2D6(C) mutant allele involves deletion of 3 base pairs in exon 5 , resulting in a single amino acid deletion in the protein. The protein produced appears to function, but at markedly reduced levels. ${ }^{38}$ In individuals with the 2D6(D) mutation, the entire gene is deleted, resulting in an $\mathbf{1 1 . 5}$ kb fragment. ${ }^{39}$ Using PCR and RFLP analysis, these four mutant alleles have been shown to account for over $95 \%$ of deficient metabolizers of debrisoquine with approximately $43,31,14$ and $9 \%$ of the mutant alleles in poor metabolizers associated with the 29(B), $44 \mathrm{~kb}, 11.5$ and 29(A) fragments, respectively. ${ }^{40}$ Using a nested primer strategy, allele specific oligonucleotide probing of PCR amplified DNA has correctly predicted $100 \%$ of extensive metabolizers and $86 \%-97 \%$ of poor metabolizers in two large independent population studies. ${ }^{41,42}$

The frequency of the poor metabolizer debrisoquine phenotype appears to be markedly lower in non-Caucasian populations. Conflicting studies have reported $8.6^{43}$ and $0 \%$ of black Nigerians to be poor metabolizers. ${ }^{44}$ In 80 Ghanaians, no individuals were poor metabolizers of sparteine while $6 \%$ were poor metabolizers of debrisoquine ${ }^{45}$ Similarly, black South Africans exhibited no evidence of poor metabolism for sparteine. ${ }^{46}$ African American children had a lower incidence of the poor metabolizer phenotype for debrisoquine $(1.9 \%)$ compared with Caucasian children $(7.7 \%){ }^{47}$ The incidence of poor metabolizers in Orientals, including Japanese, Thai, Malaysian, and Chinese populations, appears to be $0-2 \%{ }^{48-52}$ A low incidence of the debrisoquine polymorphism has been reported in other ethnic groups of Mongolian origin with $3.2 \%$ and $0 \%$ of Greenlanders and Amerindians phenotyped as poor metabolizers, respectively ${ }^{53.54}$ The regulation of sparteine and debrisoquine oxidation may be different in different ethnic groups. ${ }^{45,55}$

PCR techniques to determine CYP2D6 genotypes are highly accurate ${ }^{41,42}$ and genetic influences account for 0.79 of variation in the activity of the debrisoquine enzyme, with non-genetic factors such as age, smoking, and alcohol use having little or no impact on enzyme activity. ${ }^{48.56}$ Thus, PCR determina- 
tions of genotype may replace debrisoquine phenotype studies for some purposes. Genotyping may be useful when subjects are already taking inducers or inhibitors which alter phenotype or when giving a probe compound or collecting total urine may be medically or ethically difficult. Pregnant, pediatric, and geriatric patients may be examples of the latter; however, information regarding hormonally or developmentally induced alterations in enzyme activity must be considered. For instance, during pregnancy, the hepatic clearance of metoprolol, an antihypertensive metabolized by CYP2D6, increases with resulting plasma concentrations being only $12 \%$ to $55 \%$ of those seen in the nonpregnant state. ${ }^{57}$ Thus, although genotyping may be easier to perform than phenotyping, the application to specific clinical questions may be less direct.

\section{MEPHENYTOIN HYDROXYLATION (CYTOCHROME P4502C)}

The observation of unusual clinical sensitivity to a low dose of the anticonvulsant drug mephenytoin led to the discovery of this genetic polymorphism. ${ }^{58,59}$ Mephenytoin is a chiral compound that displays stereoselective metabolism in vivo. In normal or extensive metabolizers, S-mephenytoin is oxidized to 4'-hydroxymephenytoin, which is then excreted as the glucuronide conjugate over about 4 days, while the R-enantiomer is preferentially $\mathrm{N}$-demethylated and slowly excreted with only about $10 \%$ excreted in 14 days. ${ }^{80}$ Thus, in the normal individuals, the clearance of the S-enantiomer is about 200 -fold greater than the R-enantiomer. ${ }^{60}$ In genetically deficient subjects, this stereoselectivity is virtually absent and both enantiomers undergo demethylation and slow excretion. The mephenytoin polymorphism and this change in stereoselective metabolism is generally described using 8-hour urinary $R / S$ mephenytoin ratios with extensive and poor metabolizers having very low ratios and ratios of 1 or more, respectively. Poor metabolizers of mephenytoin are characterized by a high $\mathrm{Km}$ and a low Vmax for S-mephenytoin hydroxylation. ${ }^{24}$ This is consistent with results of in vitro studies using human autoantibodies suggesting that the mephenytoin hydroxylation deficiency is caused by a structural change leading to a functionally altered enzyme. $^{61}$ Family studies suggest the defect in S-mephenytoin hydroxylation is consistent with autosomal recessive inheritance. ${ }^{62.63}$ The enzyme responsible for mephenytoin hydroxylation has not been identified; however, it is believed to belong to the Cytochrome P4502C family. Although 4-hydrox- ylation of R-mephenytoin is catalyzed by $2 \mathrm{C9}$, no activity has been observed against S-mephenytoin. ${ }^{64}$

A small number of other drugs cosegregates with mephenytoin. Mephenytoin hydroxylase catalyzes the $3^{\prime}$-hydroxylation of hexobarbital. ${ }^{65,66}$ The oxidation of mephobarbital cosegregates with mephenytoin hydroxylation, ${ }^{67,68}$ and the incidence of adverse reactions to mephobarbital is similar to the incidence of slow metabolizers. ${ }^{49,69}$ Because tolbutamide hydroxylase copurified with mephenytoin hydroxylase, tolbutamide oxidation was believed to cosegregate with mephenytoin hydroxylation. However, no cosegregation of poor metabolizers occurs, ${ }^{70}$ and tolbutamide is oxidized by both CYP2C8 and C9, neither of which metabolize S-mephenytoin. Mephenytoin $4^{\prime}$ hydroxylation is inhibited in vitro by cortisone and ethinyloestradiol and weakly by cortisol, estradiol, adrenosterone, and testosterone. ${ }^{71}$ Competitive inhibition occurs with ethotoin, mephobarbital, methsuximide, phensuximide, and high doses of warfarin. ${ }^{72}$ Other commonly used anticonvulsants such as ethosuximide, phenobarbital, phenytoin, diazepam, and primidone do not competitively inhibit. $^{72}$ An aryl residue alpha to the carbonyl carbon of an $\mathrm{N}$-alkyl lactam in a 5 or 6 membered ring is a minimal requirement for interaction with the $4^{\prime}$ hydroxylase.

The defect in S-mephenytoin metabolism is found in about $2-5 \%$ of Caucasian populations ${ }^{73.74}$ and 18 $23 \%$ of Japanese populations. ${ }^{49.50}$ In Chinese populations, studies report $5-17.4 \%$ poor metabolizers. ${ }^{30,74}$ In contrast, no poor metabolizers were identified in 90 Panamanian Amerindians. ${ }^{75}$ The relative importance of genetic and non-genetic influences on mephenytoin hydroxylase is unknown; however, among extensive metabolizers, clearance of S-mephenytoin varies by more than an order of magnitude, suggesting non-genetic influences are important. Age may have an influence on mephobarbital hydroxylation, which cosegregates with mephenytoin oxidation. ${ }^{78}$ The suggestion of an age specific effect of gender overlooked likely confounding from oral contraceptive use. ${ }^{76,77}$

\section{OTHER CONJUGATION POLYMORPHISMS: GLUTATHIONE AND METHYL TRANSFERASES}

Glutathione S-transferases (GSTs) comprise a family of proteins that conjugate electrophilic molecules with glutathione to render them less toxic. The multiples forms of GST are divided into three classes, acidic, neutral and basic, based on their pH in isoelectric focusing. Each class shares significant physical and immunologic properties and substrate specifici- 
ties. Three genetic loci, GST1, GST2, and GST3, encoding human liver GST isoenzymes have been characterized. ${ }^{78-80}$ Of these, the GST1 locus, which encodes for the neutral mu form, appears to be polymorphic with three possible alleles, GST1-0 (null), GST1-1 and GST1-2. ${ }^{81}$ Although mu GST is a relatively small contributor to total GST activity, this polymorphism is of interest because of the relatively high specific activity of the mu class for epoxides. ${ }^{82}$ The null variant is found in every ethnic group tested thus far with a gene frequency ranging from 43 to $82 \%{ }^{78,83}$ Individuals who are homozygous for the null allele have significantly lower total GST activity $^{79}$ and lack any immunologically detectable GST1 isozyme. ${ }^{\text {ot }}$ The other possible alleles at the GST1 locus, GST1-1 and GST1-2, have been cloned and sequenced; however, the localization of the human mu class genes has not been resolved. ${ }^{85,86}$

Methylation, an important pathway for many drugs, neurotransmitters and xenobiotics, is catalyzed by a number of enzymes, two of which exhibit genetic polymorphism. Thiopurine methyl transferase (TPMT) and thiomethyl transferase (TMT) have been identified in the human red blood cell and act on thiol groups. ${ }^{87.88}$ TPMT is present in the red blood cell lysate and catalyzes methylation of 6-thioguanine, azathioprine and 6-mercaptopurine. ${ }^{89}$ Segregation analysis of family studies suggests TPMT enzyme activity is controlled by a single locus with two alleles. ${ }^{90}$ Eighty nine percent of Caucasians have high TPMT activity and represent the homozygous high activity genotype, while $11 \%$ have intermediate activity and are heterozygotes. ${ }^{90}$ Rare individuals lack TPMT activity and are homozygous for the low activity allele. This phenotype distribution yields low and high activity allele frequencies of $6 \%$ and 94\%, respectively. The activity of TPMT in the red blood cell correlates well with the relative activity in other sites, including the lymphocyte, kidney and liver. ${ }^{91-93}$ Low levels of activity reflect quantitatively low enzyme concentrations. ${ }^{92}$ The biochemical and physical properties of TPMT are similar in animals with low and high activity, suggesting a non-structural polymorphism. ${ }^{94}$ The other polymorphic methyl transferase, thiol methyltransferase (TMT), is membrane bound and catalyzes the methylation of a number of nonpurine molecules, such as 2-mercaptoethanol, captopril, and $\mathrm{N}$-acetylcysteine. ${ }^{95}$ The biochemical properties of human liver TMT are very similar to those of human red blood cell TMT. ${ }^{96}$ TMT activity in red blood cells is genetically regulated with about $98 \%$ heritability. ${ }^{97}$ Fifty-eight percent of individuals have high activity, whereas $42 \%$ have low activity. ${ }^{98}$ Whether genetic variation in red blood cell membrane TMT parallels the variation of TMT in other tissues is unknown.

\section{OTHER OXIDATIVE POLYMORPHISMS: ALCOHOL DEHYDROGENASE AND ALDEHYDE DEHYDROGENASE}

Twin studies suggest that genetic factors play a role in the threefold intersubject variation observed in ethanol metabolism. ${ }^{99,100}$ Both alcohol dehydrogenase, which oxidizes ethanol to acetaldehyde, and aldehyde dehydrogenase, which oxidizes acetaldehyde to acetate, exhibit genetic polymorphism. Alcohol dehydrogenase is a dimeric enzyme whose subunit chains are determined by at least six genetic loci, of which at least two, $A D H 2$ and $A D H 3$ are polymorphic. ${ }^{101}$ The three possible alleles at the polymorphic $A D H 2$ locus determine subunit chains called $\beta 1$, $\beta 2$, and $\beta 3$, and the two possible $A D H 3$ locus alleles result in $\tau 1$ and $\tau 2$ subunit chains (Table IV). These subunit chains hybridize to form homo or heterodimers which vary markedly in their kinetic properties. Allele frequencies vary across ethric groups (Table V). ${ }^{102}$ Isolation, purification and sequencing of the isoenzymes led to the development of specific oligonucleotides to detect complementary sequences in cDNA libraries. cDNA clones were then used to detect complimentary sequences in the libraries of human genomic DNA, leading to the isolation of genomic clones for each chain. Both polymorphic ADH loci have been localized to the long arm of chromosome $4 .{ }^{103}$ Substrate specificity studies of human ADH have largely addressed the metabolism of various alcohols, however, the oxidation of the sedative drug chloral hydrate appears to involve ADH. ${ }^{104,105}$

There are at least four forms of aldehyde dehydrogenase (ALDH) whose characteristics and activity vary substantially. ${ }^{106}$ The major isoenzyme form responsible for acetaldehyde oxidation is the mitochondrial, low $\mathrm{Km}$ form, ALDH2, encoded by the ALDH2 gene. In Asians and South American Indians,

\section{TABLE IV}

Disparity in Alcohol Dehydrogenase Isoenzyme Kinetic Constants Secondary to ADH Genetic Polymorphism

\begin{tabular}{|c|c|c|c|}
\hline Allele & Enzyme & $\underset{\text { ETOH }}{\mathrm{Km}(\mathbf{m M})}$ & $\underset{\min ^{-1}}{V_{\text {max }}}$ \\
\hline$\frac{\frac{\mathrm{ADH} 2 * 1}{\mathrm{ADH}^{*} * 2}}{\frac{\mathrm{ADH} 2^{* 3}}{\mathrm{ADH3} 3^{* 1}}}$ & $\begin{array}{l}\beta_{1} \beta_{1} \\
\beta_{2} \beta_{2} \\
\beta_{3} \beta_{3} \\
\gamma_{1} \gamma_{1} \\
\gamma_{2} \gamma_{2}\end{array}$ & $\begin{array}{c}0.05 \\
0.9 \\
34 \\
1.0 \\
0.63\end{array}$ & $\begin{array}{r}9 \\
400 \\
300 \\
87 \\
35\end{array}$ \\
\hline
\end{tabular}

(Data from Bosron and Li, 1987). 
TABLE V

Frequency of Polymorphic ADH Alleles Across Ethnic Groups

\begin{tabular}{|c|c|c|c|c|c|}
\hline & \multicolumn{3}{|c|}{ ADH2 Alleles } & \multicolumn{2}{|c|}{$\begin{array}{l}\text { ADH3 } \\
\text { Alleles } \\
\end{array}$} \\
\hline & 1 & 2 & 3 & 1 & 2 \\
\hline $\begin{array}{l}\text { Caucasians } \\
\text { Japanese } \\
\text { African Americans }\end{array}$ & $\begin{array}{r}>95 \\
35 \\
85\end{array}$ & $\begin{array}{l}<5 \\
65 \\
<5\end{array}$ & $\begin{array}{l}<5 \\
<5 \\
15\end{array}$ & $\begin{array}{l}50 \\
95 \\
85\end{array}$ & $\begin{array}{r}50 \\
5 \\
15\end{array}$ \\
\hline
\end{tabular}

a null allele at this locus causes impaired elimination of acetaldehyde and the flushing reaction following ingestion of ethanol. ${ }^{107}$ The null allele is dominant, and heterozygotes exhibit ALDH deficiency. ${ }^{108}$ The $A L D H 2$ gene has been localized to chromosome $12,{ }^{109}$ and the null allele encodes a single substitution of lysine for glutamic acid. ${ }^{110}$

\section{POLYMORPHISM OF ENZYME INDUCTION: THE Ah RECEPTOR}

Cytochrome P450 1A1 (CYP1A1), or aryl hydrocarbon hydroxylase, catalyzes the conversion of many procarcinogens into active carcinogens and is induced by various polycyclic aromatic hydrocarbons. CYP1A1 induction is a multistep process which has been elucidated using murine models. ${ }^{111-114}$ The first step requires the presence of a cytosolic receptor protein, the $\mathrm{Ah}$ receptor, whose presence is determined by a genetic polymorphism at the Ah locus. The inducing agent binds to this Ah cytosolic receptor; subsequently, the inducer-receptor complex gains chromatin binding properties. The inducer-receptor complex binds to regulatory elements upstream from the CYP1A1 coding site. The Ah receptor has been refractory to purification; however, it is thought that at least two proteins are involved. ${ }^{115}$ The molecular mechanisms and the epidemiology of Ah induction in humans is currently under investigation. Consistent with animal models demonstrating the genetic basis for Ah inducibility, ${ }^{115,116}$ induction in human lymphocytes appears trimoidal with segregation analysis strongly suggestive of a single diallelic locus determining the response. ${ }^{117}$

\section{DEVELOPMENTAL ASPECTS OF GENETICALLY POLYMORPHIC PATHWAYS}

Although characterization of the ontogeny of the genetically polymorphic pathways is incomplete, several in vitro studies of human fetal liver tissue and a limited number of in vivo clinical studies have been reported. Acetylation of the polymorphic NAT2 substrate 7-clonazepam was absent in human fetal liver at 11 and 14 weeks, with some activity starting at 16 weeks. ${ }^{118}$ However, at gestational ages up to 22 weeks, NAT2 activity is less than $1 \%$ of adult activity and bimodality is not detectable. CYP2D6 is not active early in gestation, as codeine and dextromethorphan oxidation also do not occur in human fetal liver at 14-24 weeks gestation. ${ }^{119}$ An increase in immunochemically detected protein occurs during the first postnatal week, irrespective of gestational age. ${ }^{120,121}$ The increase in protein is associated with the onset of dextromethorphan O-demethylation and is preceded by a rise in CYP2D6 mRNA, suggesting that regulation early is life is primarily at the transcriptional level. In vitro evaluation of a single human fetal liver suggests that hexobarbital hydroxylation, which cosegregates with mephenytoin hydroxylation, does not occur during mid-gestation. ${ }^{122}$ This finding is consistent with the lack of hexobarbital oxidation observed in sheep fetuses between 12 and 20 weeks. ${ }^{122}$

Glutathione transferase is present in the fetus as early as 11 weeks. ${ }^{123}$ Fetal hepatic GST activity is about two-thirds of adult activity, and non-hepatic fetal activity may actually exceed adult activity. ${ }^{124,125}$ The polymorphic mu form of glutathione transferase has not been easy to observe in the fetus before 30 weeks gestation, but does increase steadily after that time with normal adult values reached late in infancy ${ }^{126}$ Other GST isoforms, alpha and pi glutathione transferase, are similar to the corresponding adult forms. ${ }^{127,128}$ TPMT and TMT activities are present at in human fetal liver at mid-gestation, but the activities are about one third and one sixth that of adult activity, respectively. ${ }^{129,130}$ Interestingly, fetal renal TPMT is about twice that of adult hepatic TPMT. For TMT activity, no correlation is observed between fetal hepatic activity and gestational age, suggesting that late antenatal or postnatal ontogeny is important. ${ }^{129}$

ADH activity is present in human fetal liver at about 2 months, but at about $3 \%$ of adult activity. ${ }^{131}$ Human hepatic ADH activity continues to increase during gestation and early childhood with adult activity reached by age 5 . The ontogeny of hepatic ADH involves a sequential initiation of expression of the genetically regulated $\mathrm{ADH}$ isoenzymes with $\alpha$ chain production beginning in the first fetal trimester, $\beta$ chains in the second trimester and $\tau$ chains after birth. ${ }^{132}$ The temporal expression correlates with sequential promoter activation of the corresponding $\mathrm{ADH}$ alleles by hepatic nuclear factor 1 (HNF-1), CCAAT/enhancer-binding protein (C) EBP $\alpha$ ) liver activator protein (LAP) and D-element binding protein (DBP). ${ }^{133}$ 
In vivo phenotype studies of the genetically polymorphic pathways in children have been delayed compared with adult studies, partially related to the potential toxicity of the probe substrates classically used in adult studies. Ethically, a probe for use in pediatric patients should be an innocuous, easily administered compound likely to be taken by a large number of children with a phenotype determination that is noninvasive, either using urine or salivary sampling. Dextromethorphan, a common ingredient in nonprescription cough medicine, is oxidized by CYP2D6 to dextrophan, and the urinary metabolic ratio of the parent drug to its metabolite yields phenotypes that totally cosegregate with phenotypes determined with debrisoquine. ${ }^{134,135}$ Caffeine, commonly consumed by children in soft drinks, undergoes complex metabolism; however, the urinary ratio of two metabolites, 5-acetylamino-6-formylamino-3methyluracil (AFMU) and 1-methylxanthine (1X) cosegregates with acetylation phenotypes that were determined using sulfamethazine. ${ }^{136}$ Evans and colleagues determined CYP2D6 oxidation and acetylation phenotypes in 26 children (ages 3-21, median 10 yr) using dextromethorphan cough syrup and caffeine-containing cola. ${ }^{137}$ Unfortunately, in the urine samples of many children, dextromethorphan could not be detected. Although the extensive debrisoquine oxidation phenotype could be assigned, quantitative metabolic ratios could not be determined. The distribution of $\mathrm{N}$-acetylation and debrisoquine ratios in children were similar to those of adult populations. Fifty-eight percent of children were fast acetylators and $8 \%(2 / 26)$ children were poor metabolizers of dextromethorphan. A comparable incidence (6.4\%) of dextromethorphan poor metabolizers was reported in 31 healthy children, ages 5-16. ${ }^{138}$

In a study of the maturation of caffeine metabolism in 14 infants, the oldest infant (age 588 days) was a fast acetylator, while the remaining infants (ages 19434 days) were slow acetylators. ${ }^{139}$ The phenotype of a single patient studied longitudinally changed from slow to fast between 54 and 196 days of age. ${ }^{139}$ These results are consistent with the fetal liver data and the increased incidence of slow acetylator phenotype in neonates $(83 \%){ }^{140}$ The mechanism underlying slow acetylation at very early ages is unknown and may involve insufficient Coenzyme-A synthesis in addition to NAT2 maturation.

\section{SIGNIFICANCE OF DRUG METABOLISM POLYMORPHISMS: PHARMACOKINETICS, TOXICITY, AND EFFICACY}

Those authors questioning the clinical significance of genetic polymorphisms ${ }^{141}$ should remember that genetic polymorphisms of oxidative drugs were dis- covered because astute investigators wondered about the mechanisms underlying unusual adverse side effects. Genetic polymorphism may result in accumulation of the parent drug, reduced formation of an active metabolite, accumulation of an active metabolite or accumulation of the parent drug and the active metabolite. The determinants of the extent of pharmacokinetic consequences include the amount of hepatic clearance and the relative importance of the defective pathway. In addition to the magnitude of genetically-induced differences in drug disposition, the quantity of clinical use, pharmacodynamic properties of a drug and the size of its therapeutic index are important determinants of clinical significance. The presence of clinical or paraclinical drug effects which may be used for titrating the drug dose decreases the need for a priori knowledge regarding genetic differences. Thus, theoretically, therapeutic decisions regarding drugs subject to genetic polymorphism which have widespread clinical use, a low therapeutic index and no means to titrate the dose on the basis of immediate clinical measures of effect would be facilitated by genotype knowledge. Generally, adverse reactions are more frequent in poor metabolizers, with extensive metabolizers at greater risk for decreased efficacy. However, if drug effect is dependent on an active metabolite, the opposite may occur, with poor metabolizers at risk for decreased efficacy and extensive metabolizers at risk for increased toxicity.

The antiarrhythmic drug encainide undergoes $\mathrm{Cy}$ tochrome P4502D(6) oxidation to several metabolites, O-desmethylencainide (ODE), $\mathrm{N}$-desmethylencainide (NDE), 3-methoxy-O-desmethylencainide (MODE), and $\mathrm{N}$-O-didesmethylencainide. ${ }^{142} \mathrm{ODE}$ is a more potent antiarrhythmic agent than the parent drug, while MODE and NDE appear about equipotent to encainide. ${ }^{143-145}$ The characteristic electrocardiographic effects associated with antiarrhythmic action, namely an increase in QRS duration, are best correlated with plasma ODE. ${ }^{146}$ With either oral or intravenous administration, poor metabolizers have plasma encainide concentrations that are 10-20-fold higher than extensive metabolizers, and the half life is prolonged by three-fourfold with a significant accumulation of unchanged drug. ${ }^{142}$ Equally importantly, poor metabolizers have tenfold lower concentrations of ODE associated with an absence of QRS changes. ${ }^{142}$

Flecainide is an effective antiarrhythmic agent whose major metabolic pathway to meta-O-dealkylated flecainide cosegregates with that of sparteine/ debrisoquine oxidation, resulting in a tenfold difference in metabolic clearance. ${ }^{147} \mathrm{~A}$ number of patient deaths in association with high serum flecainide concentrations have been reported. ${ }^{148}$ In poor meta- 
bolizers, increased renal elimination of unchanged drug occurs. However, in renal failure, disposition of flecainide proceeds almost entirely by hepatic oxidation. ${ }^{149}$ Thus, therapy in poor metabolizers with renal failure requires close monitoring and reductions greater than that suggested with renal failure alone.

Propafenone, a Class I antiarrhythmic agent, is metabolized by both 5-hydroxylation and N-dealkylation. The hydroxylation reaction cosegregates with the debrisoquine polymorphism and poor metabolizers exhibit impaired 5-hydroxylation resulting in very low or absent levels of this active metabolite. ${ }^{28.150}$ The disposition of the parent drug in poor metabolizers is also altered with largely missing first pass metabolism, greater bioavailability, dramatically reduced apparent oral clearance and much higher steady state concentrations. These higher parent drug concentrations are associated with a greater frequency of CNS side effects in poor metabolizers (67\%) compared with extensive metabolizers (14\%). ${ }^{28}$ Propafenone is delivered as a racemate with both enantiomers exhibiting similar activity on sodium channels. However the S-enantiomer is 100 -fold more potent at $\beta$ receptor blockade. ${ }^{150}$ The relationship between the $R$ and $S$ enantiomers is similar in extensive metabolizers and poor metabolizers, but greater concentrations of the S-enantiomer in poor metabolizers may place the poor metabolizer at greater risk of $\beta$ blockade related side effects. ${ }^{151} \mathrm{Fur}$ thermore, propafenone therapy is frequently combined with a $\beta$ blocking agent. When given with metoprolol, the oral clearance of metoprolol decreases two fold, while no difference is seen in the metabolism of propafenone. This suggests the dose of metoprolol should be reduced when propafenone is given. ${ }^{152}$

Codeine O-demethylation to its active moiety, morphine, correlates with debrisoquine hydroxylation ability. ${ }^{153-155}$ In poor metabolizers and in quinidine-transformed extensive metabolizers, significant morphine production is absent and is associated with a lack of analgesia. ${ }^{156}$ In contrast, extensive metabolizer subjects demonstrate measurable morphine and both subjective and objective increases in pain thresholds.

Tricyclic antidepressants undergo 2-hydroxylation which is CYP2D6 mediated and 10-hydroxylation and demethylation which is not. ${ }^{157}$ The demethylated metabolites also undergo hydroxylation which is CYP2D6 dependent. ${ }^{158}$ The first pass metabolism of imipramine in poor metabolizers is less than in extensive metabolizers; however, the difference is less dramatic than expected because the process is saturated in extensive metabolizers. ${ }^{159}$ As a result of impaired elimination in poor metabolizers, accumu- lation of the secondary amine metabolites which are effective antidepressants may occur with an increased risk of side effect. ${ }^{160}$ However, in a small study, the incidence of imipramine related side effects in 5 poor metabolizers was not different than the incidence in 103 extensive metabolizers. ${ }^{161}$ Therapeutic management of tricyclic therapy is complicated because symptoms of excessive drug concentrations are similar to those of the disease process under treatment. The metabolic ratio for debrisoquine has been shown to correlate well with plasma nortriptyline and desipramine concentrations, suggesting knowledge of CYP2D6 activity might be helpful in therapeutic decision making. ${ }^{159} \mathrm{~A}$ second complicating factor in tricyclic therapy is the frequent use of combination therapy with neuroleptic drugs. Several reports indicate that neuroleptics inhibit the in vivo metabolism of tricyclic antidepressants. ${ }^{162}$ This inhibition is at least partially CYP2D6 dependent as the neuroleptics are competitive inhibitors of human liver microsomal metabolism of spartein $e^{163}$ and debrisoquine, ${ }^{164}$ and neuroleptic therapy has been shown to increase the metabolic ratio of sparteine and debrisoquine in vivo. ${ }^{29,165}$ In addition to inhibition of CYP2D6, some of the neuroleptics, such as perphenazine are substrates for CYP2D6, ${ }^{168}$ while others such as haloperidol are not. ${ }^{165}$

TPMT genotype is an important risk factor for the development of thiopurine-induced myelosuppression. Both 6-mercaptopurine and azathioprine are converted into 6-thioguanine ${ }^{167}$ Red blood cell 6thioguanine concentrations are directly correlated with adverse effects and inversely correlated with TPMT concentrations. ${ }^{168.169}$ Leukemic children with lower TPMT activity are at greater risk of 6-MP induced myelosuppression. In a retrospective study of 21 patients, all five subjects developing azathioprine-induced myelosuppression had low or absent TPMT levels. ${ }^{170}$ The mechanism for the inverse relationship between TPMT and 6-thioguanine is unknown.

Recent work suggests a correlation between the genetic polymorphisms for the enzymes involved in alcohol metabolism and in vivo ethanol metabolism. In the Chinese, both the ALDH2 and ADH2 genotypes influence the alcohol metabolic rate, the alcohol-flush reaction and susceptibility to alcoholism. ${ }^{171}$ In the African American population, controlling for the impact of alcohol intake, the presence of the $A D H 2 * 3$ allele has been shown to impact ethanol disposition. ${ }^{172}$ Caucasians and native Americans do not exhibit variation at these $A D H 2$ and $A L D H 2$ loci, and genetic explanations for the intersubject differences in ethanol metabolism in these populations have not been reported. The mechanism of alcohol 
related flushing occasionally reported in Caucasians and American Indians is unknown but does not appear related to an $A L D H 2 * 2$ allele.

\section{SIGNIFICANCE OF DRUG METABOLISM POLYMORPHISMS: DISEASE SUSCEPTIBILITY}

The activation of chemical toxicants and carcinogens by drug metabolizing enzymes is believed important in the pathophysiology of carcinogenesis, mutagenesis, and teratogenesis, as well as other environmentally-induced diseases. Host susceptibility may be partially explained by variation in the genetic control of the activity and inducibility of these enzymes. The association between cancer risk and genetic polymorphisms has been evaluated for $\mathrm{N}$ acetylation, the debrisoquine oxidation, mephenytoin oxidation, and glutathione transferase. Several carcinogenic arylamines, including 2-aminofluorene, methylene-bis-orthochloroaniline, benzidine and $\alpha$ and $\beta$ naph thylamine are detoxified by acetylation by NAT2. ${ }^{173}$ In contrast, the alternate pathway, $\mathrm{N}$-hyroxylation, is the first step in the formation of toxic metabolites. N-hydroxylation, followed by $\mathrm{O}$ acetylation, leads to the formation of acetoxyl arylamines. These derivatives break down spontaneously to form highly reactive arylnitrenium ions, the ultimate metabolite responsible for carcinogenesis and mutagenesis. ${ }^{174}$ NAT activity has been reported in human bladder, ${ }^{175}$ an interesting finding in view of the $39 \%$ increase in the incidence of slow acetylation in bladder cancer patients compared to matched controls. ${ }^{176.177}$ Colonic cancer is associated with the fast acetylator phenotype. ${ }^{178}$ The incongruity between increased risk of bladder cancer in slow acetylators and increased risk of colon cancer in fast acetylators is unexplained; however, organ specific expression of $\mathrm{N}$ - and $\mathrm{O}$-acetyltransferase may be a significant factor. In contrast to bladder cancer and colon cancer, acetylator status and lung cancer risk appear unrelated. ${ }^{179}$

Extensive metabolism of debrisoquine may be a genetic risk factor for bronchogenic carcinoma; however, this is controversial. Ayesh and coworkers reported that among smokers, very rapid metabolizers of debrisoquine were overrepresented among patients with lung cancer. ${ }^{180}$ In a second study controlling for age, gender and smoking, non-occupationally exposed extensive metabolizers of debrisoquine were found to be at a 4 fold increased risk for lung cancer. ${ }^{181}$ When combined with asbestos exposure, the relative risk of lung cancer in extensive metabolizers increased 18 fold. In a conflicting report, Speirs and colleagues found no difference in the frequency distribution of debrisoquine metabolism in lung cancer patients compared to controls. ${ }^{182}$ Similar debrisoquine metabolic ability was reported in bladder cancer patients and controls. ${ }^{183}$ However, in a study in which patients were differentiated by histological criteria, aggressive bladder cancer was strongly associated with efficient debrisoquine metabolism. ${ }^{184}$ Cytochrome P450 2D6 is not known to activate any known carcinogens; therefore, the relationship between extensive debrisoquine genotype and carcinogenesis likely reflects genetic linkage.

Presence of the GST1 null allele may predispose to cancer. Using the mu-specific substrate, trans-stilbene oxide, presence of mu GST activity correlates with inhibition of aflatoxin1 DNA adduct formation, ${ }^{185.186}$ suggesting an important role for this enzyme in detoxification reactions that relate to cancer risk. The high substrate selectivity of GST1 for epoxides suggests that individuals deficient in GST1 may be at increased risk for cellular and genetic damage following epoxide exposure. The frequency of GST1 deficiency is greater in heavy smokers with lung cancer compared with heavy smokers without lung cancer. ${ }^{187}$ The number of GST1 alleles correlates with mu GST activity in lung tissue ${ }^{188}$ and high levels of lung mu GST are associated with a decreased risk of lung cancer in smokers. ${ }^{188}$ Similarly, individuals who lack mu GST activity are at a threefold greater risk of adenocarcinoma of the stomach and colon. ${ }^{189}$ The association of AH inducibility with susceptibility to lung cancer was first suggested by Kellerman ${ }^{180}$ and affirmed by the association between high aryl hydrocarbon hydroxylase activity in lymphocytes and lung cancer. ${ }^{191}$

Increased risk for xenobiotic-induced nonmalignant diseases may also be related to genetic differences in metabolic ability. Acetylator status is a risk factor for hydralazine or procainamide-induced SLE. ${ }^{2.192}$ In contrast, idiopathic SLE does not appear related to acetylator status. ${ }^{193}$ The distribution of debrisoquine phenotypes is altered in patients with systemic lupus erythematosus with an increase in poor metabolizers $(21 \%)$ relative to the incidence in healthy volunteers (8\%). ${ }^{194}$ Although previous reports using urinary ratios are conflicting, ${ }^{195-107}$ individuals with the mutant forms of CYP2D6 alleles exhibit a two and a half fold increase in risk for Parkinson's disease. ${ }^{198}$ Support for the involvement of CYP2D6 in Parkinson's disease includes observations that a substrate of CYP2D6, 1-methyl-4-phenyl 1,2,3,6-tetrahydropyridine (MPTP) induces a form of Parkinsonism. ${ }^{199}$ Also, within the brain, CYP2D6 is localized to the substantia nigra, the area involved in Parkinsonism, ${ }^{200}$ and CYP2D6 has been shown to metabolize several neurotransmitter antagonists. ${ }^{201,30}$ 


\section{SIGNIFICANCE OF DRUG METABOLISM POLYMORPHISMS: BIRTH DEFECTS}

Explanations for the variation in fetal susceptibility to teratogen exposure include differences in the timing and extent of exposure. Analogous to carcinogenic risk, teratogenic risk may involve intersubject variation in the conversion of a proteratogen to either a non-toxic metabolite or to the proximate teratogen. Genetic control of the rates of formation and metabolism of reactive metabolites could determine the availability of these toxic metabolites to bind covalently with either cell macromolecules or DNA, leading to either cell death or mutations. Because maternal metabolic ability is generally orders of magnitude greater than fetal ability, for many exposures it is likely a dominant factor. A report of disparate outcome in heteropaternal twins following intrauterine exposure to phenytoin ${ }^{202}$ suggested that genetic differences in the fetus also can influence the likelihood of drug- or xenobiotic-induced teratogenicity. Inherited decreased phenytoin detoxification, documented by cytotoxicity, was observed in 14 of 24 children exposed to phenytoin throughout pregnancy. ${ }^{203}$ Twelve of the 14 children had major birth defects, compared with 2 of the 10 children with normal cytotoxic responses to phenytoin. Studies in an animal model suggest genetically controlled inducibility of maternal and fetal hepatic aryl hydrocarbon hydrolase is a factor in environmentally induced birth defects. ${ }^{204}$ In an animal model, exposure to benzyopyrene in offspring who were highly $\mathrm{Ah}$ inducible resulted in an increase in binding of benzyopyrene, more fetal resorptions, more birth defects and poorer growth only if the mother was noninducible. If the mother had high activity, presumably maternal metabolism of benzopyrene protected the fetus. Similar studies are currently underway to evaluate the alcohol dehydrogenase genotype of mothers and offspring to test whether these factors help explain the variation in alcohol related birth defects.

\section{THE FUTURE}

Continued advances in molecular biology will lead to more information regarding the mechanisms and consequences of genetically-determined intersubject variation in drug metabolism. Over the next several years, increasing availability of genetic data regarding an individual's inherited ability to metabolize drugs will likely guide therapeutic decisions, including drug choice, drug dose, and optimum therapeutic monitoring. The ability to determine genotype reliably using PCR technology will facilitate large-scale multinational epidemiologic studies of cancer, birth defects, and other environmentally induced diseases that may be associated with genetic polymorphisms. Multiple genetic polymorphisms of xenobiotic metabolism may be synergistic as risk factors. For example, for some diseases, extensive metabolism for phase I reactions, which generally generate toxic metabolites or intermediates, combined with poor metabolic ability for phase II reactions, which generally detoxify compounds, will represent the greatest risk. Ultimately, the results of these large-scale studies of multiple pathways may lead to the prevention of exposure in at-risk individuals, the detection of xenobiotic-induced disease earlier, or improved treatment using either conventional or genetic therapy.

\section{REFERENCES}

1. Batchelor JR, Welsh KI, Mansilla-Tinoco R, Dollery CT, Hughes GRV, Bernstein R, Ryan P, Naish PF, Aber GM, Bing RF, Russell GI: Hydralazine-induced systemic lupus erythematosus: Influence of HLA-DR and sex on susceptibility. Lancet 1980; i:11071109.

2. Perry HM, Tan EM, Carmody S, Sakamoto A: Relationship of acetyl transferase activity to antinuclear antibodies and toxic symptoms in hypertensive patients treated with hydralazine. $J$ Lab Clin Med 1970;76:114-125.

3. Devadatta S, Gangadharam PRJ, Andrews RH, Fox W, Ramakrishnan CV, Selkon JB, Velu S: Peripheral neuritis due to isoniazid. Bull WHO 1960; 23:587-598.

4. Pounder RE, Craven ER, Henthorn JS, Bannatyne JM: Red cells abnormalities associated with sulphasalazine maintenance therapy for ulcerative colitis. Gut 1975;16:181-185.

5. Gangadharam PRJ, Bhatia AL, Radhkrishna S, Selkon JB: Rate of inactivation of isoniazid in South-Indian patients with pulmonary tuberculosis. Bull WHO 1961;25:765-777.

6. Grant DM, Blum M, Beer M, Meyer UA: Monomorphic and polymorphic human arylamine $\mathrm{N}$-acetyltransferases: A comparison of liver isozymes and expressed products of two cloned genes. Mol Pharmacol 1990;39:184-191.

7. Hearse DJ, Weber WW: Multiple N-acetyltransferases and drug metabolism: Tissue distribution, characterization and significance of mammalian N-acetyltransferase. Biochem J 1973;132: 519-526.

8. Drayer DE, Stron JM, Jones B, Sandler A, Reidenberg MM: In vitro acetylation of drugs by human blood cells. Drug Metab Dispos Biol Fate Chem 1974;2:499-505.

9. Mandelbaum-Shavit F, Blondheim SH: Acetylation of p-aminobenzoic acid by human blood. Biochem Pharmacol 1981; 30:65-69. 10. Grant DM, Morike K, Eichelbaum M, Meyer UA: Acetylation Pharmacogenetics, The slow acetylator phenotype is caused by decreased or absent arylamine $\mathrm{N}$-acetyltransferase in human liver. J Clin Invest 1990;85:968-972.

11. Blum M, Grant DM, McBride W, Heim M, Meyer UA: Human arylamine $\mathrm{N}$-'cetyltransferase genes: Isolation, chromosomal location and function expression. DNA Cell Biol 1990;9:193-203.

12. Ohsako S, Deguchi T: Cloning and expression of cDNAs for polymorphic and monomorphic arylamine $\mathrm{N}$-acetyltransferases from human liver. J Biol Chem 1990; 285:4630-4634.

13. Grant DM, Blum M, Demierre A, Meyer UA: Nucleotide sequence of an intronless gene for a human arylamine $\mathrm{N}$-acetyl- 
transferase related to polymorphic drug acetylation. Nucl Acids Res 1989; 17:3978.

14. Hickman D, Sim E: N-acetyltransferase polymorphism comparison of phenotype and genotype in humans. Biochem Pharmacol 1991;42:1007-1014.

15. Deguchi T: Sequences and expression of alleles of polymorphic arylamine $\mathrm{N}$-acetyltransferase of human liver. J Biol Chem 1992; 267-272.

16. Horai $Y$, Ishizaki $\mathrm{T}$ : N-Acetylation polymorphism of dapsone in a Japanese population. $\mathrm{Br}$ J Clin Pharmacol 1988;25:487-494.

17. Mahgoub A, Dring LG, Idle JR, Lancaster R, Smith RL: Polymorphic hydroxylation of debrisoquine in man. Lancet 1977; i:584-586.

18. Eichelbaum M, Spannbrucker N, Steincke B, Dengler HJ: Defective $\mathrm{N}$-oxidation of sparteine in man: a new pharmacogenetic defect. Eur J Clin Pharmacol 1979;16:183-187.

19. Bertilsson L, Dengler HJ, Eichelbaum M, Schulz HU: Pharmacogenetic covariation of defective $\mathrm{N}$-oxidation of sparteine and 4-hydroxylation of debrisoquine. Eur $J$ Clin Pharmacol 1980; 17:153-155.

20. Otton SV, Inaba T, Mahon WA, Kalow W: In vitro metabolism of sparteine by human liver: competitive inhibition by debrisoquine. Can J Physiol Pharmacol 1982;60:102-105.

21. Evans DAP, Mahgoub A, Sloan TP, Idle JR, Smith RL: A family and population study of genetic polymorphism of debrisoquine oxidation in a White British population. J Med Genet 1980;17:102105.

22. Steiner E, Bertilsson L, Sawe J, Bertling I, Sjoqvist F: Polymorphic debrisoquin hydroxylation in 757 Swedish subjects. Clin Pharmacol Ther 1988;44:431-435.

23. Distlerath LM, Reilly PEB, Martin MV, Davis GG, Wilkinson GR, Guengerich FP: Purification and characterization of the human liver cytochromes $P-450$ involved in debrisoquine 4-hydroxylation and phenacetin O-deethylation, two prototypes for genetic polymorphism in oxidative drug metabolism. I Biol Chem 1985;260:9057-9067.

24. Meyer UA, Gut J, Kronbach T, Skoda C, Meier UT, Catin T: The Molecular mechanisms of two common polymorphisms of drug oxidation-evidence of functional changes in cytochrome P450 isozymes catalyzing bufuralol and mephenytoin oxidation. Xenobiotica 1986; 16:449-464.

25. Lennard MS, Tucker GT, Silas JH, Freestone S, Ramsay LE and Woods HF: Differential stereoselective metabolism of metoprolol in extensive and poor debrisoquin metabolisers. Clin Pharmacol Ther 1983;34:732-737.

26. Brosen K, Gram LF: First pass metabolism of imipramine and desipramine: Impact of the sparteine oxidation phenotype. Clin Pharmacol Ther 1988;43:400-406.

27. Leemann T, Dayer P, Meyer UA: Single dose quinidine treatment inhibits metoprolol oxidation in extensive metabolizers. Eur J Clin Pharmacol 1986; 29:739-741.

28. Siddoway LA, Thompson KA, McAllister B, Wang T, Wilkinson GR, Roden DM, Woosley RL: Polymorphism of propafenone metabolism and disposition in man: clinical and pharmacokinetic consequences. Circulation 1987;4:785-791.

29. Syvalanti EK, Lindberg R, Kallio J, De Vocht M: Inhibitory effects of neuroleptics on debrisoquine oxidation in man. Br J Clin Pharmacol 1986;22:89-92.

30. Fonne-Pfister R, Meyer UA: Xenobiotic and endobiotic inhibitors of cytochrome P450dbl function, the target of the debrisoguine/sparteine type polymorphism. Biochem Pharmacol 1988; 37:3829-3835.

31. Eichelbaum M, Mineshita S, Ohnhaus EE, Zekorn C: The in- fluence of enzyme induction on polymorphic sparteine oxidation. Br J Clin Pharmacol 1986;22:49-53.

32. Gonzalez FJ, Vilbois F, Hardwick JP, McBride OW, Nebert DW, Gelboin HV, and Meyer UA: Human debrisoquine 4-hydroxylase (P450IID1):cDNA and deduced amino acid sequence and assignment of the CYP2D locus to chromosome 22. Genomics 1988;2:174-179.

33. Skoda RC, Gonzalez FJ, Demierre A, Meyer UA: Two mutant alleles of the human cytochrome P450dbl gene (P450C2D1) associated with genetically deficient metabolism of debrisoquine and other drugs. Proc Natl Acad Sci USA 1988;85:5240-5243.

34. Evans WE, Relling MV: XbaI 16-plus 9-kilobase DNA restriction fragments identify a mutant allele for debrisoquine hydroxylase: Report of a family study. Mol Pharmacol 1990;37:632-642.

35. Kagimoto M, Heim M, Kagimoto K, Zeugin T, Meyer UA: Multiple mutations of the human cytochrome P450IID6 gene (CYP2D6) in poor metabolizers of debrisoquine: Study of the functional significance of individual mutations by expression of chimeric genes. J Biochem 1990; 265:17209-17216.

36. Heim M, Meyer UA: Evolution of a highly polymorphic gene locus for a drug metabolizing enzyme. Genomics 1992; 14:49-58. 37. Johansson I, Yue QY, Dahl ML, Heim M, Sawe J, Bertilsson L, Meyer UA, Sjoqvist F, Ingelman-Sundberg M: Genetic analysis of the interethnic difference between Chinese and Caucasians in the polymorphic metabolism of debrisoquine and codeine. $\mathrm{Br} \mathrm{J}$ Clin Pharmacol 1991;40:553-556.

38. Tyndale R, Aoyama T, Broly F, Matsunaga T, Inaba T, Kalow W, Gelboin HV, Meyer UA, Gonzalez FJ: Identification of a new variant CYP2D6 allele lacking the codon encoding Lys-281:Possible association with the poor metabolizer phenotype. Pharmacogenetics 1991;1:26-32.

39. Gaedigk A, Blum M, Gaedigk R, Eichelbaum, Meyer UA: Deletion of the entire cytochrome P450 CYP2D6 gene as a cause of impaired drug metabolism in poor metabolizers of the debrisoquine/sparteine polymorphism. Am J Hum Genet 1991;48:943950.

40. Heim M, Meyer UA: Genotyping of poor metabolizers of debrisoquine by allele-specific PCR amplification. Lancet 1990; 336:529-532.

41. Broly F, Gaedigk A, Heim M, Eichelbaum M, Morike K, Meyer UA: Debrisoquine/sparteine hydroxylation genotype and phenotype: analysis of common mutations and alleles of CYP2D6 in a European population. DNA Cell Biol 10:545-558, 1991.

42. Dahl ML, Johansson I, Palmertz MP, Ingelman-Sundberg $M$, Sjoqvist F: Analysis of the CYP2D6 gene in relation to debrisoquin and desipramine hydroxylation in a Swedish population. Clin Pharmacol Ther 1992;51:12-17.

43. Mbanefo C, Bababunmi EA, Mahgoub A, Sloan TP, Idle JR, Smith RL: A study of debrisoquine hydroxylation polymorphism in a Nigerian population. Xenobiotica 1980;10:811-818.

44. Iyun AO, Lennard MS, Tucker GT, Woods HF, Phil D: Metoprolol and debrisoquin metabolism in Nigerians: Lack of evidence for polymorphic oxidation. Clin Pharmacol Ther 1986;40:387-394. 45. Woolhouse NM, Eichelbaum M, Oates NS, Idle JR, Smith RL: Dissociation of co-regulatory control of debrisoquin/phenformin and sparteine oxidation in Ghanaians. Clin Pharmacol Ther 1985; 37:512-521.

46. Sommers DK, Moncrieff J, Avenant JC: Absence of polymorphism of sparteine oxidation in the South African Venda. Hum Exp Toxicol 1991;10:175-178.

47. Relling MV, Cherrie J, Schell MJ, Petros WP, Meyer WH, Evans WE: Lower prevalence of the debrisoquin oxidative poor metabolizer phenotype in American black versus white subjects. Clin Pharmacol Ther 1991;50:308-313. 
48. Wanwimolruk S, Patamasucon P, Lee EJD: Evidence for the polymorphic oxidation of debrisoquine in the Thai population. $\mathrm{Br}$ J Clin Pharmacol 1990;29:244-247.

49. Nakamura K, Goto E, Ray WA, McAllister CB, Jacqz E, Wilkinson GR, Branch RA: Interethnic differences in genetic polymorphism of debrisoquin and mephenytoin hydroxylation between Japanese and Caucasian populations. Clin Pharmacol Ther 1985:38:402-408.

50. Horai $Y$, Nakano $M$, Ishizaki $T$, Ishikawa $K$, Zhou HH, Zhou BJ, Liao CL, Zhang LM: Metoprolol and mephenytoin oxidation polymorphisms in far eastern Oriental subjects: Japanese versus mainland Chinese. Clin Pharmacol Ther 1989;46:198-205.

51. Lee EJD, Yeoh PN, and Gong NH: Oxidation phenotyping in Chinese and Malay populations. Clin Exp Pharmacol Physiol 1988; 15:889-891.

52. Lou Y, Ying L, Bertilsson L, Sjoqvist F: Low frequency of slow debrisoquine hydroxylation in a native Chinese population. Lancet 1987; ii:852-853.

53. Brosen K: Sparteine oxidation polymorphism in Greenlanders living in Denmark. Br J Clin Pharmacol 1986;22:415-419.

54. Arias TD, Jorge LF, Lee D, Barranres R, and Inaba T: The oxidative metabolism of sparteine in the Cuna Amerindians of Panama: Absence of evidence for deficient metabolizers. Clin Pharmacol Ther 1988;443:456-465.

55. Horai $Y$, Taga J, Ishizaki $T$, Ishikawa $K$ : Correlations among the metabolic ratios of three test probes (metoprolol, debrisoquine and sparteine) for genetically determined oxidation polymorphism in a Japanese population. Br J Clin Pharmacol 1990;29:111115.

56. Steiner E, Iselius L, Alvan G, Lindsten J, Sjoqvist F: A family study of genetic and environmental factors determining polymorphic hydroxylation of debrisoquin. Clin Pharmacol Ther 1985; 38:394-401.

57. Hogstedt S, Lindberg B, Peng DR, Regardh CG, Rane A: Pregnancy-induced increase in metoprolol metabolism. Clin Pharmacol Ther 1985; 37(6):688-692.

58. Kupfer A, Desmond V, Schenker S, Branch RA: Stereoselective metabolism and disposition of the enantiomers of mephenytoin during chronic oral administration of the racemic drug in man. J Pharmacol Exp Ther 1982;221:590-597.

59. Kupfer A, Desmond $P$, Patwardham R, Schenker S, Branch RA: Mephenytoin hydroxylation deficiency: kinetics after repeated doses. Clin Pharmacol Ther 1984;35:33-39.

60. Wedlund PJ, Aslanian WS, Jacqz E, McAllister CB, Branch RA, Wilkinson GR: Phenotypic differences in mephenytoin pharmacokinetics in normal subjects. I Pharmacol Exp Ther 1985;234:662-669.

61. Meier UT, Meyer UA: Genetic polymorphism of human cytochrome P450 (S)-mephenytoin 4-hydroxylase. Studies with human autoantibodies suggest a functionally altered cytochrome P-450 isozyme as cause of the genetic deficiency. Biochemistry 1987;26:8466-8474.

62. Inaba $T$, Jurima $M$, Kalow $W$ : Family studies of mephenytoin hydroxylation deficiency. Am J Hum Genet 1986; 38:768-772.

63. Ward SA, Goto F, Nakamura K, Jacqz E, Wilkinson GR, Branch RA: S-mephenytoin 4-hydroxylase is inherited as an autosomal recessive trait in Japanese families. Clin Pharmacol Ther 1987;42:96-99.

64. Relling MV, Aoyama T, Gonzalez FJ, Meyer UA: Tolbutamide and mephenytoin hydroxylation by human cytochrome P450s in the CYP2C subfamily. J Pharmacol Exp Ther 1990;252:4427.

65. Knodell RG, Dubey RK, Wilkinson GR, Guengerich FP: Oxidative metabolism of hexobarbital in human liver: Relationship to polymorphic S-mephenytoin 4-hydroxylation. J Pharmacol Exp Ther 1988; 245:845-849.

66. Yasumori T, Murayama N, Yamazoe Y, Kata R: Polymorphism in hydroxylation of mephenytoin and hexobarbital stereoisomers in relation to hepatic P450 human-2. Clin Pharmacol Ther 1990; 47:313-322.

67. Jacqz E, Hall SD, Branch RA, Wilkinson GR: Polymorphic metabolism of mephenytoin in man: Pharmacokinetic interaction with a co-regulated substrate, mephobarbital. Clin Pharmacol Ther 1986;39:646-653.

68. Kupfer A, Branch RA: Stereoselective mephobarbital hydroxylation cosegregates with mephenytoin hydroxylation. Clin Pharmacol Ther 1985; 38:414-418.

69. Eadie MJ, Bochner F, Hooper WD, Tyrer JH: Preliminary observations on the pharmacokinetics of methylphenobarbitone. Clin Exp Neurol 1978;15:131-144.

70. Knodell RG, Hall SD, Wilkinson GR, Guengerich FP: Hepatic metabolism of tolbutamide: Characterization of the form of cytochrome P450 involved in methyl hydroxylation and relationship to in vivo disposition. J Pharmacol Exp Ther 1987;241:11121119.

71. Jurima M, Inaba T, Kalow W: Mephenytoin hydroxylase activity in human liver: inhibition by steroids. Drug Metab Disp Biol Fate Chem 1985; 13:746-749.

72. Hall SD, Guengerich FP, Branch RA, and Wilkinson GR: Characterization and Inhibition of Mephenytoin 4-hydroxylase activity in human liver microsomes. J Pharmacol Exp Ther 1987;240:1:216-222.

73. Wedlund PJ, Asianian WS, McAllister CB, Wilkinson GR, Branch RA: Mephenytoin hydroxylation deficiency in Caucasians: frequency of a new oxidative drug metabolism polymorphism. Clin Pharmacol Ther 1984;36:773-780.

74. Jurima M, Inaba T, Kadar D, Kalow W: Genetic polymorphism of mephenytoin $p(4)$-hydroxylation: difference between Orientals and Caucasians. Br J Clin Pharmacol 1985; 19:483-487.

75. Inaba T, Jorge LF, Arias TD: Mephenytoin hydroxylation in the Cuna Amerindians of Panama. Br J Clin Pharmacol 1988;25:75-79.

76. Chandler MHH, Scott SR, Blouin RA: Age-associated stereoselective alterations in hexobarbital metabolism. Clin Pharmacol Ther 1988;43:436-441.

77. Waxman DJ: Interactions of hepatic cytochromes P450 with steroid hormones. Biochem Pharmacol 1988;37:71-64.

8. Board PG: Biochemical genetics of glutathione S-transferase in man. Am J Hum Genet 1981;33:36-43.

79. Board PG:Gene deletion and partial deficiency of the glutathione S-transferase (ligandin) system in man. FEBS Lett 1981;135:12-14.

80. Strange RC, Faulder CG, Davis BA, Hume R, Brown JAH, Cotton W, Hopkinson DA: The human glutathione S-transferases: Studies on the tissue distribution and genetic variation on the GST1, GST2, and GST3 isozymes. Am J Hum Genet 1984;48:11-20. 81. Laisney V, Cong NV, Ross, MS and Frezal, J: Human genes for glutathione S-transferases. Hum Genet 1984;68:221-227.

82. Warholm M, Guthenberg C, Mannervick B: Molecular and catalytic properties of glutathione transferase mu from human liver: An enzymes efficiently conjugating epoxides. Biochemistry 1983;22:3610-3617.

83. Fryer AA, Zhao L, Alldersea J, Boggild MD, Perrett CW, Clayton RN, Jones PW, Strange RC: The glutathione S-transferases: Polymerase chain reaction studies on the frequency of the GSTM1 0 genotype in patients with pituitary adenomas. Carcinogenesis 1993; 14:563-566. 
8. Suzuki T, Coggan M, Shaw DC, Board PG: Electrophoretic and immunological analysis of human glutathione S-transferase isoenzymes. Ann Hum Genet 1987;51:95-106.

85. De Jong JL, Chang C-M, Whang-Peng J, Knutsen T, Tu C-PD: The human liver glutathione S-transferase gene superfamily: Expression and chromosome mapping of an $\mathrm{Hb}$ subunit cDNA. Nucl Acids Res 1988;16(17):8541-8554.

86. Isalm MQ, Platz A, Szpirer J, Szpirer C, Levan G, Mannervik B: Chromosomal localization of human glutathione transferase genes of classes alpha mu and pi. Hum Genet 1989;82:338-342.

87. Weinshilboum RM, Raymond FA, Pazmino PA: Human erythrocyte thiopurine methyltransferase: radiochemical micro assay and biochemical properties. Clin Chim Acta 1978;85:323-333.

88. Weinshilboum RM, Sladek S, Klumpp S: Human erythrocyte thiol methyltransferase:radiochemical micro assay and biochemical properties. Clin Chim Acta 1979; 97:59-71.

89. Remy CN: Metabolism of thiopyrimidines and thiopurines: S-methylation with S-adenosylmethionine transmethylase and catabolism in mammalian tissue. J Biol Chem 1963;238:1078-1084.

80. Weinshilboum RM, Sladek SL: Mercaptopurine pharmacogenetics: Monogenic inheritance of erythrocyte thiopurine methyltransferase activity. Am J Hum Genet 1980; 32:651-662.

91. Van Loon JA, Weinshilboum RM: Thiopurine methyltransferase biochemical genetics: human lymphocyte activity. Biochem Genet 1982;20:637-658.

92. Woodson LC, Dunnette JH, Weinshilboum RM: Pharmacogenetics of human thiopurine methyltransferase: Kidney-erythrocyte correlation and immunotitration studies. J Pharmacol Exp Ther 1982;222:174-181.

83. Szumlanski CL, Scott MC and Weinshilboum RM: Thiopurine methyltransferase pharmacogenetics: Human liver enzyme activity. Clin Pharmacol Ther 1988;43:134

84. Otterness DM, Weinshilboum RM: Mouse thiopurine methyltransferase pharmacogenetics: Biochemical studies and recombinant inbred strains. J Pharmacol Exp Ther 1987;243:180-186.

95. Keith RA, Jardine I, Kerremans A, Weinshilboum RM: Human erythrocyte membrane thiol methyltransferase: S-methylation of captopril, N-acetylcysteine and 7- $\alpha$-thio-spirolactone. Drug Metab Dispos Biol Fate Chem 1984;12:717-724.

88. Glauser TA, Kerremans AL, Weinshilboum: Human hepatic microsomal thiol methyltransferase: Assay conditions, biochemical properties, and correlations studies. Drug Metab Dispos 1992; 20:247-255.

87. Keith RA, Van Loon J, Wussow LF, Weinshilboum RM: Thiol methylation pharmacogenetics: Heritability of human erythrocyte thiol methyltransferase activity. Clin Pharmacol Ther 1883; 34:521-528.

83. Price RA, Keith RA, Spielman RS, Weinshilbaum RM: Major gene polymorphism for human erythrocyte (RBC) thiol methyltransferase (TMT). Genet Epidemiol 1989;6:651-662.

89. Kopun M, Proppin P: The kinetics of ethanol absorption and olimination in twins and supplementary repetitive experiments in singleton subjects. Eur J Clin Pharmacol 1977;11:337-433.

100. Martin NG, Perl J, Oakeshott JG, Gibson JB, Starmer JA, Wilks AV: A twin study of ethanol metabolism. Behav Genet 1985;15:93-109.

101. Burnell JC, Bosron WF: Genetic polymorphism of human liver alcohol dehydrogenase and kinetic properties of the isoenzymes. In Cro KE. Batt RD (eds.): Human Metabolism of Alcohol, Vol II. Boca Raton, FL: CRC Press, 1989;65-75.

102. Bosron WF, Li T-K: Catalytic properties of human liver alcohol dehydrogenase isoenzymes. Enzyme 1987;37:19-28.

103. Tsukahara M, Yoshida A: Chromosomal assignment of the alcohol dehydrogenase cluster locus to human chromosome 4q21-23 by in situ hybridization. Genomics 1989;218-220.

104. Kassam JP, Tang BK, Kadar D, Kalow W: In vitro studies of human liver alcohol dehydrogenase variants using a variety of substrates. Drug Metab Dispos Biol Fate Chem 1989;1:567-572.

105. Friedman PJ, Cooper JR: The role of alcohol dehydrogenase in the metabolism of chloral hydrate. J Pharmacol Exp Ther 1960; 129:372-376.

106. Goedde HW, Agarwal DP: Pharmacogenetics of aldehyde dehydrogenase (ALDH). Pharmacol Ther 1990;45:345-371.

107. Mizoi Y, Tatsuno Y, Adachi J, Kogame M, Fukunaga T, Fujiwara S, Hishida S, Ijiri I: Alcohol sensitivity related to polymorphism of alcohol-metabolizing enzymes in Japanese. Pharmacol Biochem Behav 1983;18:127-133.

108. Crabb DW, Edenberg HJ, Bosron WF, Li TK: Genotypes for aldehyde dehydrogenase deficiency and alcohol sensitivity. The inactive $\mathrm{ALDH}^{2}$ allele is dominant. J Clin Invest 1989;83:314-316. 109. Hsu LC, Yoshida A, Mohandas T: Chromosomal assignment of the genes for human aldehyde dehydrogenase-1 and aldehyde dehydrogenase-2. Am J Hum Genet 1986;38:641-648.

110. Yoshida A, Huang I, Ikawa M: Molecular abnormality of an inactive aldehyde dehydrogenase variant commonly found in Orientals. Proc Natl Acad Sci USA 1984;81:248-261.

111. Nebert DW, Gielen JE: Genetic regulation of aryl hydrocarbon hydroxylase induction in the mouse. Fed Proc 1972;31:13151325.

112. Thomas PE, Kouri RE, Hutton JJ: The genetics or aryl hydrocarbon hydroxylase induction in mice: a single gene difference between C57B1/6J and DBA/2J. Biochem Genet 1972;6:157-168. 113. Denison MS, Fisher JM, Whitlock JP: The DNA recognition site for the dioxin-Ah receptor complex. Nucleotide sequence and functional analysis. J Biol Chem 1988;263:17221-17224.

114. Neuhold LA, Shirayoshi Y, Ozata K, Jones JE, Nebert DW: Regulation of mouse CYP1A1 gene expression by dioxin. Requirment of two cis-acting elements during the induction process. Mol Cell Biol 1989; 9:2378-2386.

115. Nebert DW, Goujan FM, Gielen HE: Aryl hydrocarbon hydroxylase induction by polycyclic hydrocarbons: Simple autosomal dominant trait in the mouse. Nature N Biol 1972;236:107-110. 116. Thomas PE, Kouri RE, Hutton J]: The genetics of aryl hydrocarbon hydrooxylase induction in mice: A single gene difference between C57BL/6J and DBA/2J. Biochem Genet 1972;6:157-168 117. Kellerman G, Luyten-Kellerman M, Shaw CR: Genetic variation of aryl hydrocarbon hydroxylase in human liver cytosol. Am J Hum Genet 1973;25:327-331.

118. Peng DR, Birgersson C, von Bahr C, Rane A: Polymorphic acetylation of 7-aminoclonazepam in human liver cytosol. Pediatr Pharmacol 1984;4:155-159.

119. Ladona MG, Lindstrom Bjorn, Thyr C, Peng DR, Rane A: Differential fetal development of the $\mathrm{O}$ - and $\mathrm{N}$-demethylation of codeine and dextromethophan in man. Br J Clin Pharmacol 1991; 323:295-302.

120. Treluyer JM, Jacqz-Aigrain E, Alvarez F, Cresteil T: Expression of CYP2D6 in developing human liver. Eur J Biochem 1991;202:583-588.

121. Spina E, Pacifici GM, VonBahr C, Rane A: Characterization of desmethylimipramine 2-hydroxylation in human fetal and adult liver microsomes. Acta Pharmacol Toxicol 1986; 58:277-281. 122. Dvorchik BH, Woodward G, Sitar DS, Tweed WA: Hydroxylation and glucuronidation of various xenobiotics by hepatic microsomes from fetal lamb, pregnant ewe and human fetus. Dev Pharmacol Ther 1986; 9:282-9.

123. Pacifici GM, Frenchi M, Colizzi C, Giuliana L, Rane A: Gluta- 
thione S-transferase in humans: Development and tissue distribution. Arch Toxicol 1988;61:265-269.

124. Beckett GJ, Howie AF, Hume R, Matharoo B, Hiley C, Jojes $P$, Strange Rc: Human glutathione S-transferases: Radioimmunoassay studies on the expression of alpha-, mu- and pi-class isoenzymes in developing lung and kidney. Biochim Biophys Acta 1990; 1036:176-182.

125. Strange RC, Howie AF, Hume R, Matharoo B, Bell J, Hiley C, Jones P, Beckett GJ: The development expression of alpha-, mu-, and pi-class glutathione S-transferases in human liver. Biochim Biophys Acta 1989; 993:186-190.

126. Strange Rc, Davis Ba, Faulder CG, Cotton W, Bain AD, Hopkinson DA, Hume R: The human glutathione S-transferases: Developmental aspects of the GST1, GST2, and GST3 loci. Biochem Genet 1985;23:1011-1023.

127. Guthenberg C, Warholm M, Rane A, Mannervik B: Two distinct forms of glutathione transferase from human fetal liver. Purification and comparison with isoenzymes isolated from adult liver and placenta. Biochem J 1986;235:741-745.

128. Pacifici GM, Guthenberg C, Warholm M, Mannervik B, Rane A: Conjugation of styrene oxide by the basic and acidic forms of glutathione transferase in the human fetal liver. Dev Pharacol Ther 1988; 11(4):243-251.

129. Pacifici GM, Santerini S, Giuliani L, Rane A: Thiol methyltransferase in humans: Development and tissue distribution. Dev Pharmacol Ther 1991;17:8-15.

130. Pacifici GM: Romiti P, Giuliana L, Rane A: Thiopurine Methyltransferase in humans:Development and tissue distribution. Dev Pharmacol Ther 1991;17:16-23.

131. Pikkarainen PH, Raiha NCR: Development of alcohol dehydrogenase activity in the human liver. Pediatr Res 1967;1:165168.

132. Smith M, Hopkinson D, Harris H: Development changes and polymorphism in human alcohol dehydrogenase. Ann Hum Genet 1971;34:251-271.

133. van Ooij C, Snyder RC, Paeper BW, Duester G: Temporal expression of the human alcohol dehydrogenase gene family during development correlates with differential promoter activation by hepatocyte nuclear factor 1,CCAAT/enhancer-binding protein $\alpha$, liver activator protein, and D-element-binding protein. $\mathrm{Mol}$ Cell Biol 1992; 12:3023-3031.

134. Kupfer A, Schmid B, Preisig R, et al: Dextromethorphan as a safe probe for debrisoquine hydroxylation polymorphism. Lancet 1984; 2:517-518.

135. Schmid B, Bircher J, Preisig R, et al: Polymorphic dextromethorphan metabolism: Co-segregation of oxidative O-demethylation with debrisoquin hydroxylation. Clin Pharmacol Ther 1985; 38:618-624.

136. Grant DM, Tang Bk, Kalow W: A simple test for acetylator phenotype using caffeine. Br J Clin Pharmacol 1984; 17:459-464.

137. Evans WE, Relling MV, Petros WP, Meyer WH, Mirro J, Crom WR: Dextromethorphan and caffeine as probes for simultaneous determination of debrisoquin-oxidation and $\mathrm{N}$-acetylation phenotypes in children. Clin Pharmacol Ther 1989;45:568-573.

138. Jacqz-Aigrain E, Laurent J, Alvarez F: Dextromethorphan phenotypes in paediatric patients with autoimmune hepatitis. $\mathrm{Br} J$ Clin Pharmacol 1990;30(1):153-154.

139. Carrier O, Pons G, Rey E, Richard MO, Moren C, Badoual J, Olive G: Maturation of caffeine metabolic pathways in infancy. Clin Pharmacol Ther 1988;44(2):145-151.

140. Szorady I, Santa A, Veress I: Drug Acetylator phenotypes in newborn infants. Biol Res Pregn Perinatol 1987;8:23-25.
141. Polymorphic Drug Oxidation - Much Ado About Nothing. Lancet 1984; 1:1337.

142. Wang T, Roden DM, Wolfenden T, Woosely RL, Wood AJJ, Wilkinson GR: Influence of genetic polymorphism on the metabolism and disposition of encainide in man.J Pharmacol Exp Ther 1984; 228:605-611.

143. Gomoll AW, Byrne JE, Mayol RF: Comparative antiarrhythmic actions of encainide and its major metabolites. Arch Int Pharmacoydn Ther 1986;28:277-297.

144. Roden DM, Duff HJ, Altenbern D, Woosely RL: Antiarrhythmic activity of the O-demethyl metabolite of encainide. J Pharmacol Exp Ther 1982;221:552-557

145. Kerr MJ, Harbon DWG, Shanks RG: Effects of encainide and its metabolites on ventricular arrhythmias in dogs. Br J Pharmacol 1983; 78:126P.

146. Carey EL, Duff HJ, Roden DR, Primm RK, Wilkinson GR, Wang T, Oates JA, Woosley RL: Encainide and its metabolites: Comparative effects in man on ventricular arrhythmia and electrocardiographic intervals. J Clin Invest 1984; 73:539-547.

147. Mikus G, Gross AS, Beckmann J Hertrampj r, Gundert-Remy $\mathrm{U}$, Eichelbaum M: The influence of the sparteine/debrisoquin phenotype on the disposition of flecainide. Clin Pharmacol Ther 1989;45:562-567.

148. Spivack C, Gottlieb S, Miura DS, Somberg JC: Flecainide toxcity. Am J Cardiol 1984;53:329-330.

149. Forland SC, Burges E, Blair AD, Cutler RE, Kvam DC, Weeks CE ET AL:Oral flecainide pharmacokinetics in patients with impaired renal function. J Clin Pharmacol 1988; 28:259-267.

150. Kroemer HK, Funck-Brentano C, Silberstein DJ, Wood AJJ, Eichelbaum M, Woosley RL, Roden DM: Stereoselective disposition and pharmacologic activity of propafenone enantiomers. Circulation 1989;79:1068-1076.

151. Lee JT, Funck-Bretano C, Lineberry MD, Chaffin PL, Roden DM, Woosley RL: Beta receptor antagonism by propafenone in man: Influence of polymorphic metabolism. Clin Res 1988; 36:294A.

152. Wagner F, Kalusche D, Trenk D, Jason E, Roams H: Drug interaction between propafenone and metoprolol. Br J Clin Pharmacol 1987;24:213-220.

153. Yue QY, Svennson JO, Alm C, Sjoqvist F, Sawe J: Codeine O-demethylation cosegregates with polymorphic debrisoquine hydroxylation. Br J Clin Pharmacol 1989;28:639-645.

154. Dahlstrom B, Paalzow L: Pharmacokinetics and analgesia of codeine and its metabolite morphine. In: Opiates and endogenous opioid peptides. Ed Elsevier/North-Holland. Biomedical Press, Amsterdam 1976; 395-398.

155. Quiding $H$, Anderson $P$, Bondesson $U$, Boreus LO, Hynning PA: Plasma concentrations of codeine and its metabolite, morphine, after single and repeated oral administration. Eur J Clin Pharmacol 1986; 30:673-677.

156. Desmeules J, Gascon MP, Dayer P, Magistris M: Impact of environmental and genetic factors on codeine analgesia. Eur J Clin Pharmacol 1991;41:23-26.

157. Brosen K, Zengin T, Meyer UA: Role of P450IID6, the target of the sparteinedebrisoquin oxidation polymorphism, in the metabolism of imipramine. Clin Pharmacol Ther 1991;49:609-617.

158. Brosen K, Otton SV, Gram LF: Imipramine demethylation and hydroxylation: Impact of the sparteine oxidation phenotype. Clin Pharmacol Ther 1986;40:543-549.

159. Brosen K, Klysner R, Gram LF, Otton SV, Bech P, Bertilsson L: Steady state concentration of imipramine and its metabolites in relation to the sparteine/debrisoquine polymorphism. Eur J Clin Pharmacol 1986;30:679-684. 
160. Bertilsson L, Mellstrom B, Sjoqvist F, Martensson B, Asberg M: Slow hydroxylation of nortriptyline and concomitant poor debrisoquine hydroxylation: Clinical implications. Lancet 1981;i: 560-561.

161. Meyer JW, Woggon B, Kupfer A: Importance of oxidative polymorphism on clinical efficacy and side effects of imipraminea retrospective study. Pharmacopsychiatry 1988;21:365-366.

162. Nelson JC, Jatlow PI: Neuroleptic effect on desipramine steady-state plasma concentrations. Am J Psychiatr 1980;137: 1232-1234.

163. Otton SV, Inaba T, Kalow W: Inhibition of sparteine oxidation in human liver by tricyclic antidepressants and other drugs. I Life Sci 1983;32:795-800.

164. Inaba T, Nakano M, Otton SV, Majon WA, Kalow W: A human cytochrome $\mathbf{P 4 5 0}$ characterized by inhibition studies as the sperteine-debrisoquine monoxygenase. Can J Physiol Pharmacol 1984; 62:860-862.

165. Gram LF, Debruyne D, Caillard V, Boulenger JP, Lacotte J, Moulin M, Zarifan E: Substantial rise in sparteine metabolic ratio during haloperidol treatment. Br J Clin Pharmacol 1989;27:272275.

166. Dahl-Puustinen ML, Liden A, Alm C, Nordin C, Bertilsson L: Disposition of perphenazine is related to the polymorphic debrisoquin hydroxylation in man. Clin Pharmacol Ther 1989;46:78-81. 167. Lennard L, Maddocks JL: Assay of 6-thioguanine nucleotide, a major metabolite of azathioprine, 6-mercaptopurine and 6-thioguanine, in human red blood cells. I Pharm Pharmacol 1983;35:15-18.

168. Lennard L, Rees CA, Lilleyman JS, Maddocks JL: Childhood leukemia: a relationship between intracellular 6-mercaptopurine metabolites and neutropenia. Br J Clin Pharmacol 1983;16:359363.

169. Lennard L, Van Loon JA, Lilleyman JS, Weinshilboum RM: Thiopurine pharmacogenetics in leukaemia. Correlation of erythrocyte thiopurine methyltransferase activity and 6-thioguanine nucleotide concentrations. Clin Pharmacol Ther 1987;41:18-25.

170. Lennard L, Van Loon JA, Weinshilboum RM: Pharmacogenetics of acute azathioprine toxicity: relationship to thiopurine methyltransferase genetic polymorphism. Clin Pharmacol Ther 1989;46:149-54.

171. Thomasson HR, Crabb DW, Edenberg HJ. Li T-K: Alcohol and aldehyde dehydrogenase polymorphisms and alcoholism. Behav Genet 1993;23:131-136.

172. May DG, Thomasson HR, Martier S, Ager J, Durisin L, Mowery J, Reasonover L, Sokol R, Li TK: Ethanol metabolism in women: Relative imporatance of ADH genotype and intake. Alcohol Clin Exp Res 1992:16(3):605.

173. Glowinski IB, Radtke AE, Weber WW: Genetic variation in $\mathrm{N}$-acetylation of carcinogenic arylamines by human and rabbit liver. Mol Pharmacol 1978;13:940-949.

174. Glowinski IB, Weber WW, Fysh JM, Vaught JB, King CM: Evidence that arylhydroxamic acid N,O-acetyltransferase and the genetically polymorphic $\mathrm{N}$-acetyltransferase are properties of the same enzyme in rabbit liver. J Biol Chem 1980;255:7883-7890.

175. Kirlin WG, Trinidad A, Yerokun T, Ogolla F, Ferguson RJ, Andrews AF, Brady PK and Hein DW: Polymorphic expression of acetyl coenzyme A-dependent $\mathrm{N}$-acetyltransferase and acetyl coenzyme A-dependent O-acetyltransferase mediated activation of N-hydroxyarylamines by human bladder cytosol. Cancer Res 1989;49:2448-2454.

176. Evans DAP, Eze LC, Whibley EJ: The association of the slow acetylator phenotype with bladder cancer. I Med Genet $1983 ; 20: 330-333$.
177. Woodhouse KW, Adams PC, Clothier A, Mucklow JC, Rawlins MD: $\mathrm{N}$-acetylator phenotype in bladder cancer. Hum Toxicol 1982; 1:443-445.

178. Ilet KF, David BM, Detchon P, Castleden WM, Kwa R: Acetylation phenotype in colorectal carcinoma. Cancer Res 1987:47:1466-1469.

179. Philip PA, Fitzgerald DL, Cartwright RA, Peake MD, Rogers HJ: Polymorphic $\mathrm{N}$-acetylation capacity in lung cancer. Carcinogenesis 1988; 9:491-493.

180. Ayesh R, Idle JR, Ritchie JC, Crothers MJ, Hetzel MR: Motabolic oxidation phenotypes as markers for susceptibility to lung cancer. Nature (Lond.) 1984; 312:169-170.

181. Caporaso NE, Hayes RB, Dosemeci M, Hoover R, Ayesh R, Hetzel M, Idle J: Lung cancer risk, occupational exposure and the debrisoquine metabolic phenotype. Cancer Res 1989;49:36753679.

182. Speirs CJ, Murray S, Davies DS, Biolamabadeje AF, Boobis AR: Debrisoquine oxidation phenotype and susceptibility to lung cancer. Br J Clin Pharmacol 1990;29:101-109.

183. Cartwright RA, Phillip PA, Rogers JH, Glashan RW: Genetically determined debrisoquine oxidation capacity in bladder cancer. Carcinogenesis (Lond.) 1984;5:1191-1192.

184. Kaisary A, Smith P, Jaczq E, McAllister CB, Wilkinson GR, Ray WA, Branch RA: Genetic predisposition to bladder cancer: Ability to hydroxylate debrisoquine and mephenytoin as risk factors. Cancer Res 1987;47:5488-5493.

185. Seidegard J, Voracher WR, Pero RW, Pearson WR: Hereditary differences in the expression of the human glutathione transferase active on trans-stilbene oxide are due to a gene deletion. Proc Natl Acad Sci USA 1988;85:7293-7297.

186. Liu YH, Taylor J, Linko P, Lucier GW, Thompson CL: Glutathione S-transferase mu in human lymphocyte and liver: role in modulating formation of carcinogen-derived DNA adducts. Carcinogenesis 1991;12:2269-75.

187. Seidegard J, Pero RW, Miller DG, Beattie ?: A glutathione transferase in human leukocytes as a marker for the susceptibility to lung cancer. Carcinogenesis 1986; 7:751-753.

188. Nazar-Stewart V, Motulsky AG, Eaton DL, White E, Hornung SK, Lang ZT, Stapleton P, Weiss NS: The glutathione S-transferase mu polymorphism as a marker for susceptibility to lung carcinoma. Cancer Res 1993;53(10S):2313-2318.

189. Strange RC, Matharoo B, Faulder GC, Jones P, Cotton W, Elder JB, Deakin M: The human glutathione S-transferases: a casecontrol study of the incidence of the GST1-0 phenotype in patients with adenocarcinoma. Carcinogenesis 1991;12:25-28.

190. Kellerman G, Shaw CR, Layten-Kellermann M: Aryl hydrocarbon hydroxylase inducibility and bronchogenic carcinoma. $N$ Engl J Med 1973;298:934-937.

191. Kouri RE, McKinney CE, Slomiany DJ, Snodgrass DR, Wray NP, McLemore TL: Positive correlation between high aryl hydrocarbon hydroxylase activity and primary lung cancer as analysed in cryopreserved lymphocytes. Cancer Res 1982;42:5030-5037.

192. Woosley RL, Drayer DE, Reidenberg MM, Nies AS, Carr K, Oates JA: Effect of acetylator phenotype on the rate at which procainamide induces antinuclear antibodies and the lupus syndrome. N Engl J Med 1978;298:1157-1159.

193. Baer AN, Woosley RL, Pincus T: Further evidence for the lack of association between acetylator phenotype and systemic lupus erythematosus. Arthrit Rheum 1986;29:508-514.

194. Baer AN, McAllister CB, Wilkinson GR, Woosley RL, Pincus $\mathrm{T}$ : Altered distribution of debrisoquine oxidation phenotypes in patients with systemic lupus erythematosus. Arthrit Rheum $1986 ; 29: 843-850$. 
195. Benitez J, Ladero JM, Jimenez FJJ, Martinez C, Puerto AM, Valdirielso M), LLarena A, Cobaleda J, Munoz JJ: Oxidative polymorphism of debrisoquine in Parkinson's disease. J Neurol Neurosurg Psychiatr 1990;53:289-292.

188. Kallio J, Martilla RJ, Rinne UK, Sonninen V, Syvalahti E: Debrisoquine oxidation in Parkinson's disease. Acta Neurol Scand 1991;83:194-197.

197. Gudjonsson O, Sanz E, Alvan G, Aquilonius S-M, Reviriego J: Poor hydroxylator phenotypes of debrisoquine and R-Mephenytoin are not overrepresented in a group of patients with Parkinson's disease. Br J Clin Pharmacol 1990; 30:301-302.

198. Smith CAD, Gough AC, Nigel Leigh P, Summers BA, Harding AE, Maranganore DM, Sturman SG, Schapira AHV, Williams AC, Spurr NK, Wolf CR: Debrisoquine hydroxylase gene polymorphism and susceptibility to Parkinson's disease. Lancet 339:13751377.

199. Fonne-Pfister R, Bargetzi MJA, Meyer UA: MPTP the neurotoxin inducing Parkinson's disease, is a potent inhibitor of human and rat P450 enzymes (P450bufl, P450dbl) catalyzing debrisoquine 4-hydroxylation. Biochem Biophys Res Commun 1987; 148:1144-1150.

200. Nisnik HB, Tyndale RF, Sallee FR, et al.: The dopamine transporter and cytochrome P450IID1 (debrisoquine 4-hydroxylase) in brain: Resolution and identification of two distinct [ $\left.{ }^{3} \mathrm{H}\right] \mathrm{GBR}$ 12935 binding proteins. Arch Biochem Biophys 1990; 276:424-432. 201. Eichelbaum M, Gross AS: The genetic polymorphism of debrisoquine/sparteine metabolism-clinical aspects. Pharmacol Ther 1990;46:377-394.

202. Phelan MC, Pellock JM, Nance WE: Discordant expression of fetal hydantoin syndrome in heteropaternal dizygotic twins. $N$ Engl J Med 1982; 307:99-101.

203. Stickler SM, Dansky LV, Miller MA, Seni MH, Andermann E, Spielberg SP: Genetic predisposition to phenytoin-induced birth defects. Lancet 1985; 2:746-749.

204. Nebert DW: Birth defects and the potential role of genetic differences in drug metabolism. Birth Defects 1981; XVII:51-70. 